\author{
Marquette University \\ e-Publications@Marquette
}

4-2009

\title{
A Comparison of Pilot-scale Photocatalysis and Enhanced Coagulation for Disinfection Byproduct Mitigation
}

\author{
Daniel Gerrity \\ Arizona State University at the Tempe Campus \\ Brooke Mayer \\ Marquette University, Brooke.Mayer@marquette.edu \\ Hodon Ryu \\ Arizona State University at the Tempe Campus \\ John Crittenden \\ Arizona State University at the Tempe Campus \\ Morteza Abbaszadegan \\ Arizona State University at the Tempe Campus
}

Follow this and additional works at: https://epublications.marquette.edu/civengin_fac

Part of the Civil and Environmental Engineering Commons

\section{Recommended Citation}

Gerrity, Daniel; Mayer, Brooke; Ryu, Hodon; Crittenden, John; and Abbaszadegan, Morteza, "A Comparison of Pilot-scale Photocatalysis and Enhanced Coagulation for Disinfection Byproduct Mitigation" (2009).

Civil and Environmental Engineering Faculty Research and Publications. 32.

https://epublications.marquette.edu/civengin_fac/32 
Marquette University

e-Publications@Marquette

\section{Civil, Construction and Environmental Engineering Faculty Research and Publications/College of Engineering}

This paper is NOT THE PUBLISHED VERSION; but the author's final, peer-reviewed manuscript. The published version may be accessed by following the link in the citation below.

Water Research, Vol. 43, No. 6 (April 2009): 1597-1610. DOI. This article is C Elsevier and permission has been granted for this version to appear in e-Publications@Marquette. Elsevier does not grant permission for this article to be further copied/distributed or hosted elsewhere without the express permission from Elsevier.

\section{A comparison of pilot-scale photocatalysis and enhanced coagulation for disinfection byproduct mitigation}

Daniel Gerrity

National Science Foundation Water Quality Center, Department of Civil and Environmental Engineering, Arizona State University, Tempe, AZ

Brooke Mayer

National Science Foundation Water Quality Center, Department of Civil and Environmental Engineering, Arizona State University, Tempe, AZ

Hodon Ryu

National Science Foundation Water Quality Center, Department of Civil and Environmental Engineering, Arizona State University, Tempe, AZ

John Crittenden

National Science Foundation Water Quality Center, Department of Civil and Environmental Engineering, Arizona State University, Tempe, AZ

Morteza Abbaszadegan 
National Science Foundation Water Quality Center, Department of Civil and Environmental Engineering, Arizona State University, Tempe, AZ

\begin{abstract}
This study evaluated pilot-scale photocatalysis and enhanced coagulation for their ability to remove or destroy disinfection byproduct (DBP) precursors, trihalomethane (THM) formation potential (FP), and THMs in two Arizona surface waters. Limited photocatalysis $\left(<5 \mathrm{kWh} / \mathrm{m}^{3}\right)$ achieved reductions in most of the DBP precursor parameters (e.g., DOC, $U_{254}$, and bromide) but led to increased chlorine demand and THMFP. In contrast, enhanced coagulation achieved reductions in the DBP precursors and THMFP. Extended photocatalysis $\left(<320 \mathrm{kWh} / \mathrm{m}^{3}\right)$ decreased THMFP once the energy consumption exceeded $20 \mathrm{kWh} / \mathrm{m}^{3}$. The photocatalytic energy requirements for THM destruction were considerably lower (EEO $\left.=20-60 \mathrm{kWh} / \mathrm{m}^{3}\right)$ than when focusing on precursor destruction and THMFP. However, rechlorination increased the total THM (TTHM) concentration well beyond the raw value, thereby negating the energy benefits of this application. Enhanced coagulation achieved consistent $20-30 \%$ removals of preformed THMs. Outstanding issues need to be addressed before $\mathrm{TiO}_{2}$ photocatalysis is considered feasible for DBP mitigation; traditional strategies, including enhanced coagulation, may be more appropriate.
\end{abstract}

\title{
Keywords
}

Photocatalysis, Advanced oxidation, Enhanced coagulation, Disinfection byproduct, Trihalomethane

\section{Introduction}

Disinfection byproducts (DBPs), which include an ever-expanding list of chemical contaminants, have been a significant concern in the water industry for over 30 years (Richardson, 2003). The water industry's shift to alternative disinfection methods has introduced new groups of DBPs, and researchers have identified additional routes of exposure, including inhalation and dermal exposure, which may lead to adverse human health effects (Richardson, 2003). In the United States (U.S.), the Environmental Protection Agency (EPA) regulates the concentrations of total trihalomethanes (TTHMs), five haloacetic acids (HAA5), bromate, and chlorite in finished drinking water. The 2006 Stage 2 Disinfectant and Disinfection Byproduct Rule (D/DBPR) maintains existing maximum contaminant levels (MCLs) for these DBPs (i.e., $80 \mu \mathrm{g} / \mathrm{L}$ for TTHM, $60 \mu \mathrm{g} / \mathrm{L}$ for HAA5, $10 \mu \mathrm{g} / \mathrm{L}$ for bromate, and $1 \mathrm{mg} / \mathrm{L}$ for chlorite) but requires compliance based on locational running annual averages rather than the system-wide averages allowed by the Stage 1 D/DBPR (USEPA, 2006). The more stringent Stage 2 D/DBPR averaging method may force utilities to reassess their DBP mitigation strategies and possibly implement additional treatment to remain in regulatory compliance.

DBP mitigation is generally accomplished through the physical removal of organic precursor material with coagulation or enhanced coagulation coupled with flocculation, sedimentation, and filtration; granular activated carbon; or membrane filtration (Jacangelo et al., 1995, Abbaszadegan et al., 2007, Chen et al., 2007, Mayer et al., 2008). Utilities can also implement alternative disinfection strategies, including ozonation or UV disinfection, in order to meet their disinfection goals with reduced chlorine addition. However, some of these alternative disinfectants may also form DBPs (e.g., bromate from ozonation) or may be ineffective in inactivating certain pathogenic microorganisms (e.g., UV inactivation of adenoviruses).

Although these strategies are generally sufficient to control DBP formation, some utilities are considering advanced treatment technologies to provide better protection against the formation of DBPs in drinking water distribution systems. In addition to DBPs, these advanced technologies have become more viable due to an increased demand for water reuse and a greater awareness of contaminants of emerging concern (e.g., 
pharmaceuticals, endocrine disruptors, personal care products, etc.). Advanced oxidation processes (AOPs) have the ability to address all of these issues. AOPs rely on the formation of radical species by UV/hydrogen peroxide, ozone/hydrogen peroxide, titanium dioxide $\left(\mathrm{TiO}_{2}\right)$ photocatalysis, or other process combinations. The radical species, specifically hydroxyl radicals ( $\left.\mathrm{OH}_{*}\right)$, are generally nonspecific and are capable of oxidizing emerging contaminants (Barreto et al., 1995, Kaneco et al., 2004, Yu et al., 2006, Orlov et al., 2007, Thiruvenkatachari et al., 2007, Benotti et al., 2009), mineralizing DBP precursors (Hand et al., 1995, Kleiser and Frimmel, 2000, Chin and Berube, 2005, Glauner et al., 2005, Toor and Mohseni, 2007, Liu et al., 2008), and inactivating microorganisms (Matsunaga et al., 1988, Cho et al., 2005, Ryu et al., 2008, Gerrity et al., 2008).

Photocatalysis involves the irradiation of $\mathrm{TiO}_{2}$ nanoparticles with UV light $(\lambda<387 \mathrm{~nm})$ in order to produce hydroxyl radicals $\left(\mathrm{OH}_{*}\right)$ for oxidation and superoxide radicals $\left(\mathrm{O}_{2}^{-} \cdot{ }_{-}\right)$for reduction. The heterogeneous nature of the photocatalyst also provides a substrate for physical adsorption. These processes are depicted in Hand et al. (1995). With respect to DBP mitigation, the oxidation pathway allows for decomposition and mineralization of organic precursors, the reduction pathway allows for reductive dechlorination of THMs and HAAs, and the adsorption pathway allows for physical removal of the DBPs and their precursors. Furthermore, Richardson et al. (1996) reported only a single photocatalysis-specific DBP before and after chlorination.

Due to this versatility, there are several ways to incorporate $\mathrm{TiO}_{2}$ photocatalysis into a DBP mitigation strategy. In a treatment plant setting, $\mathrm{TiO}_{2}$ photocatalysis could be used to remove and mineralize precursors since DBPs may not have formed without prechlorination. On the other hand, DBPs may form in clear wells prior to distribution. Upon discharge from the clear well, the remaining DBP precursors could be mineralized, and the actual DBPs could also be destroyed before the water is released into the distribution system. Since photocatalysis will destroy a chlorine residual, the water would have to be rechlorinated prior to discharge. In both of these scenarios, the flow rates will be relatively high so it may become costly to treat the water with advanced oxidation. Therefore, it may be more practical to focus on "hot spots" (i.e., locations with high water age and/or DBP concentrations) in the distribution system due to the potential for more focused treatment, lower flow rates, and reduced energy consumption. In relation to this last scenario, Rodriguez et al. (2007) reported a direct correlation between TTHM levels and water age.

This study aims to address these three scenarios using a pilot-scale $\mathrm{TiO}_{2}$ photocatalysis reactor and two different Arizona surface waters. A range of energy consumption is evaluated in terms of THM precursor reductions, organic matter size distribution and mineralization, and reduction in THM formation potential (THMFP). Energy requirements and rate constants for the destruction of the actual THMs are also reported. Enhanced coagulation is included as a point of comparison as it has been identified as the best available technology for DBP mitigation (Jacangelo et al., 1995, Chen et al., 2007).

\section{Experimental section}

\subsection{Water sources}

Due to the high population and semiarid climate of the Phoenix metropolitan area, water resources in the region are severely strained. Since the Salt River and Central Arizona Project (CAP) Canal (Colorado River water) are two of the main surface water supplies in the region, raw water from these sources was collected for this study. Two separate samples, hereafter described as Raw 1 and Raw 2, were collected from each surface water between May and July of 2008 , when the average high temperature is above $38^{\circ} \mathrm{C}$ and average monthly precipitation ranges from 0.3 to $2.5 \mathrm{~cm}$ (National Weather Service, 2008). The samples were stored at $4{ }^{\circ} \mathrm{C}$ for no longer than $48 \mathrm{~h}$ prior to the experiments. Table 1 provides information related to raw water quality for these surface waters. 
Table 1. Raw water quality summary for the CAP Canal and Salt River.

\begin{tabular}{|c|c|c|c|c|}
\hline Parameter & CAP Canal & & Salt River & \\
\hline & Raw 1 & Raw 2 & Raw 1 & Raw 2 \\
\hline Collection date & $5 / 6 / 2008$ & $7 / 21 / 2008$ & $5 / 22 / 2008$ & $7 / 21 / 2008$ \\
\hline $\mathrm{pH}$ & 8.5 & 8.1 & 8.1 & 7.7 \\
\hline Turbidity (NTU) & 2.2 & 1.3 & 2.2 & 9.6 \\
\hline Alkalinity $\left(\mathrm{mg} / \mathrm{L}\right.$ as $\left.\mathrm{CaCO}_{3}\right)$ & 128 & 160 & 105 & 112 \\
\hline Bromide $(\mu \mathrm{g} / \mathrm{L})$ & 109 & 97 & 109 & 114 \\
\hline $\mathrm{DOC}(\mathrm{mg} \mathrm{C} / \mathrm{L})$ & 5.7 & 4.8 & 7.4 & 6.7 \\
\hline $\mathrm{UV}_{254}\left(\mathrm{~cm}^{-1}\right)$ & 0.046 & 0.049 & 0.110 & 0.110 \\
\hline SUVA (L/mg C m) & 0.81 & 1.0 & 1.5 & 1.7 \\
\hline 24-h $\mathrm{Cl}_{2}$ demand at $10^{\circ} \mathrm{Ca}, \mathrm{b}\left(\mathrm{mg} \mathrm{Cl}_{2} / \mathrm{L}\right)$ & 1.3 & $\mathrm{~N} / \mathrm{A}$ & 3.7 & $\mathrm{~N} / \mathrm{A}$ \\
\hline 24- $\mathrm{h} \mathrm{Cl}_{2}$ demand at $28^{\circ} \mathrm{C}^{\mathrm{a}}(\mathrm{mg} \mathrm{Cl} / \mathrm{L})$ & 1.9 & 3.1 & 3.9 & 5.5 \\
\hline THMFP at $10^{\circ} \mathrm{Ca}, \mathrm{b}(\mu \mathrm{g} / \mathrm{L})$ & 53 & $\mathrm{~N} / \mathrm{A}$ & 115 & $\mathrm{~N} / \mathrm{A}$ \\
\hline THMFP at $28^{\circ} \mathrm{C}^{\mathrm{a}}(\mu \mathrm{g} / \mathrm{L})$ & 83 & 95 & 165 & 146 \\
\hline
\end{tabular}

aSee experimental variables section for details on chlorination protocol and formation potential test. b10 ${ }^{\circ} \mathrm{C}$ experiments were not performed for Raw 2 samples.

\subsection{Experimental variables}

Turbidity, $\mathrm{pH}$, and several DBP-related parameters, including bromide, dissolved organic carbon (DOC), $U_{254}$ absorbance, specific UV absorbance (SUVA), and 24-h chlorine demand, were analyzed for each sample. Total trihalomethanes (TTHM) and concentrations of the individual constituents (i.e., chloroform $\left(\mathrm{CHCl}_{3}\right)$, bromodichloromethane $\left(\mathrm{CHBrCl}_{2}\right)$, dibromochloromethane $\left(\mathrm{CHBr}_{2} \mathrm{Cl}\right)$, and bromoform $\left.\left(\mathrm{CHBr}_{3}\right)\right)$ were evaluated following modified THM formation potential tests. A modified THM formation potential test was used during this study to exploit the benefits of the standard simulated distribution system (SDS) and formation potential (FP) tests. The 24-h chlorine demand of each raw surface water was determined prior to each experiment. All samples were then chlorinated with the concentration necessary to target $1 \pm 0.2 \mathrm{mg} / \mathrm{L}$ free chlorine residual in the raw waters after $24 \mathrm{~h}$. Chlorine residuals were measured and quenched with excess ascorbic acid after $24 \mathrm{~h}$ of incubation at $10^{\circ} \mathrm{C}$ or $28^{\circ} \mathrm{C}$. The samples were then preserved with hydrochloric acid $(\mathrm{pH}<2)$. For the THM removal and destruction experiments, the raw waters were prechlorinated with $7 \mathrm{mg} / \mathrm{L}$ of free chlorine.

\subsection{Analytical measurements}

The $\mathrm{pH}$ was measured using a Mettler (Columbus, $\mathrm{OH}$ ) pH meter. Turbidity was measured using a Hach (Loveland, CO) model 2100P turbidimeter. Total alkalinity was determined using a Hach model 16900 digital titrator with sulfuric acid titration cartridges and bromocresol green-methyl red indicator powder pillows. Free chlorine was analyzed using a Hach D4/4000U spectrophotometer and DPD free chlorine reagent powder pillows. Prior to the DOC, $\cup_{254}$, and bromide analyses, enhanced coagulation samples were filtered using 0.45$\mu \mathrm{m}$ Whatman (Middlesex, UK) GF/C glass microfiber filters. The enhanced coagulation samples were also acidified with $1 \mathrm{M} \mathrm{HCl}$ prior to the DOC analyses. Photocatalysis samples were filtered by the submicron-poresize ceramic membrane within the reactor and acidified with $1 \mathrm{M} \mathrm{HCl}$ prior to the DOC analyses. DOC was analyzed using a Shimadzu (Kyoto, Japan) 5050A Total Organic Carbon Analyzer. A Shimadzu Multispec 1501 spectrophotometer was used to measure $\mathrm{UV}_{254}$. Bromide was measured using a Dionex (Sunnyvale, CA) DX-120 ion chromatograph. Apparent molecular weight was determined by high-performance size exclusion chromatography with online DOC detection, according to Her et al. (2002). Samples were analyzed with a Waters (Milford, MA) Alliance 2695 Separations Module and a HW-50S Toyopearl (Stuttgart, Germany) polymeric column. The HPLC was connected to a Sievers (GE Analytical Instruments, Boulder, CO) 800 Portable TOC Analyzer. The samples were treated with $\mathrm{Na}_{2} \mathrm{SO}_{4}$ to adjust their conductivity to $4.6 \pm 0.1 \mathrm{mS} / \mathrm{cm}$, acidified 
with $6 \mathrm{M} \mathrm{H}_{3} \mathrm{PO}_{4}$, and oxidized with $15 \%$ ammonium persulfate $\left(\left(\mathrm{NH}_{4}\right)_{2} \mathrm{~S}_{2} \mathrm{O}_{8}\right)$. The eluent consisted of $0.025 \mathrm{M}$ $\mathrm{Na}_{2} \mathrm{SO}_{4}$ and a phosphate buffer $\left(0.0024 \mathrm{M} \mathrm{NaH}_{2} \mathrm{PO}_{4}+0.0016 \mathrm{M} \mathrm{Na}_{2} \mathrm{HPO}_{4}\right)$ adjusted to a $\mathrm{pH}$ of 6.8 . The ionic strength of the eluent was $0.1 \mathrm{M}$. Samples were run with $1 \mathrm{~mL}$ injection volume, eluent flow rate of $1 \mathrm{~mL} / \mathrm{min}$, and an analysis time of $100 \mathrm{~min}$. Methanol (molecular weight = $32 \mathrm{Da}$ ) and six polyethylene glycol (PEG) standards ranging from 1000 to 10,000 Da were used to convert retention time to apparent molecular weight. The THM constituents were analyzed according to EPA method 524.2 using an O.I. Analytical (College Station, TX) 4551A autosampler and 4660 concentrator. An HP-VOC capillary column (30 m $\times 200 \mu \mathrm{m} \times 1.12 \mu \mathrm{m})$ and an HP 6890 GC-MS from Agilent Technologies (Santa Clara, CA) were used.

\subsection{Pilot-scale photocatalysis}

The pilot-scale photocatalysis experiments were performed using the Photo-Cat Lab ${ }^{\circledR}$ from Purifics ${ }^{\circledR}$ (London, ON, Canada). The Photo-Cat Lab ${ }^{\circ}$ consists of an air compressor for oxygenation of the system; eight 75-watt, lowpressure, mercury arc bulbs in series; and a submicron-pore-size ceramic membrane filter that produces $\mathrm{TiO}_{2-}$ free effluent. In addition to providing oxygen to the system, the air compressor also produces a periodic air hammer to remove any $\mathrm{TiO}_{2}$ from the surface of the ceramic membrane filter. Since the filter effluent flow is perpendicular to the process flow, the $\mathrm{TiO}_{2}$ slurry is recycled through the system. Process water flows through an annular reactor formed by an outer stainless steel tube and a quartz sleeve protecting the UV bulbs. The UV path length from the quartz sleeve to the outer wall is approximately $3 \mathrm{~mm}$. A schematic of the Photo-Cat Lab ${ }^{\bullet}$ is provided in Fig. 1.

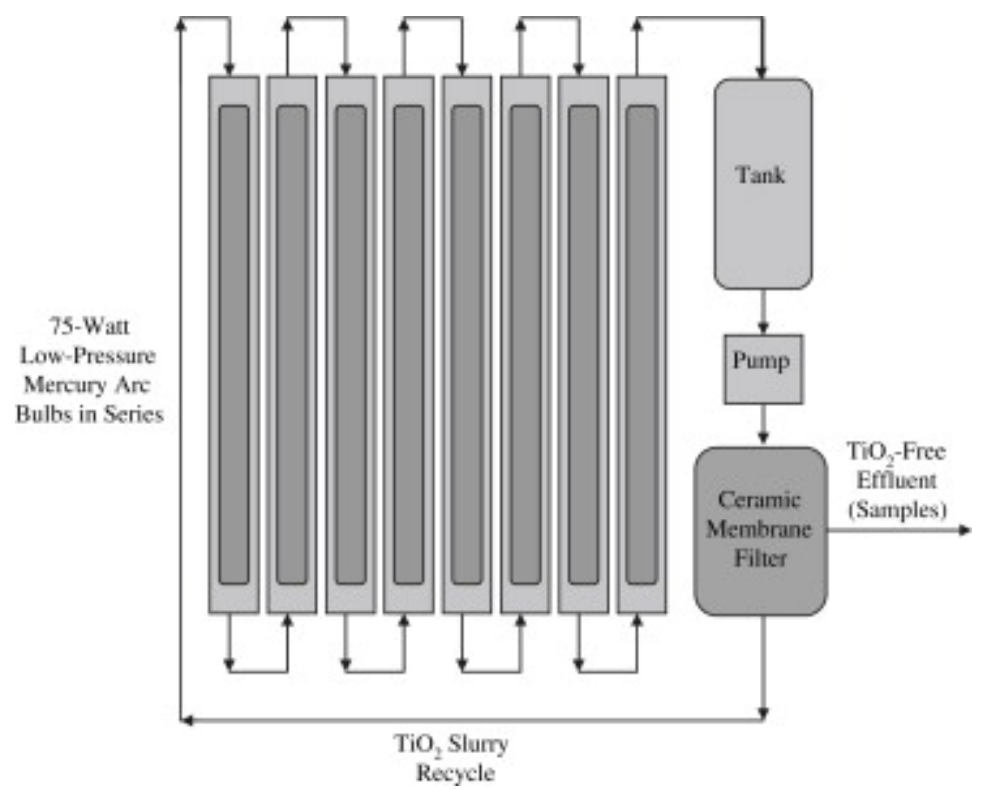

Fig. 1. Schematic of the Photo-Cat Lab ${ }^{\bullet}$

The reactor was operated in a batch configuration at a process flow rate of $25 \mathrm{~L} / \mathrm{min}$ and an initial system volume of approximately $16 \mathrm{~L}$. Volume changes due to sampling were accounted for when calculating energy consumption. The energy consumption values reported in this study are specific to the UV lamps and do not include energy consumption associated with pumping, controls, etc. Based on biodosimetry experiments with the bacteriophage MS2 (Gerrity et al., 2008), the average intensity of the UV bulbs was approximately $7.0 \mathrm{~mW} / \mathrm{cm}^{2}$. The lamps were turned on and allowed to warm up prior to the initial experiment for each phase. The water and $\mathrm{TiO}_{2}$ were allowed to mix for $3 \mathrm{~min}$, which corresponds to approximately five hydraulic residence times, prior to taking the initial samples and starting the photocatalysis reactions. Samples were taken from the effluent produced by the ceramic membrane filter. A slurry of reagent-grade Degussa $\mathrm{P}_{2} 5 \mathrm{TiO}_{2}$ (Dusseldorf, 
Germany), which consists of approximately $75 \%$ anatase and $25 \%$ rutile $\mathrm{TiO}_{2}$ (Ohno et al., 2001), was used for each experiment.

\subsection{Enhanced coagulation}

Alum and ferric chloride are the most commonly used coagulants in water treatment applications (Crittenden et al., 2005). Ferric chloride (ferric chloride hexahydrate lumps, Sigma Chemical Co., St. Louis, MO) was selected for this study because it is more efficient than alum for the removal of natural organic matter (NOM) (Crittenden et al., 2005). Enhanced coagulation doses range from 5 to $150 \mathrm{mg} / \mathrm{L} \mathrm{FeCl}_{3}$ (Jofre et al., 1995) but are commonly in the range of $20-60 \mathrm{mg} / \mathrm{L} \mathrm{FeCl}_{3}$ (Volk et al., 2000). Therefore, coagulant doses of 20, 40, and $60 \mathrm{mg} / \mathrm{L}$ $\mathrm{FeCl}_{3}$ were tested in this study. The cationic polymer poly(diallyldimethylammonium chloride) (polyDADMAC; Clarifloc 350, Polydyne, Inc., Riceboro, GA) was used in conjunction with ferric chloride to improve floc settleability. Polymer was added at a constant dose of $0.4 \mathrm{mg} / \mathrm{L}$ since variations in polymer dose have not demonstrated a significant effect on DOC removal (Kastl et al., 2004). Although the optimal pH for coagulation of NOM with ferric chloride is approximately 4-5 (Amirtharajah et al., 1993, Childress et al., 1999), practicality generally limits enhanced coagulation to a $\mathrm{pH}$ range of 5-7 (Kastl et al., 2004). Therefore, in addition to the $\mathrm{pH}$ of the raw waters, target $\mathrm{pH}$ values of $5.5,6.0,6.5$ were tested in this study.

The enhanced coagulation experiments were performed with a bench-scale jar-test apparatus (PB-700 Phipps \& Bird, Richmond, VA). The raw water was allowed to warm to room temperature prior to distributing $1.5 \mathrm{~L}$ of water to each jar. The jar-testing protocol used throughout this study was based on the protocol described by Volk et al. (2000). Immediately following chemical addition, rapid mixing was initiated at $100 \mathrm{rpm}$ $\left(G=100 \mathrm{~s}^{-1}\right)$ for $1 \mathrm{~min}$. Mixing was slowed for the flocculation stage, which consisted of two 10-min mixing periods at 40 and $20 \mathrm{rpm}$ ( $G=35$ and $15 \mathrm{~s}^{-1}$, respectively). The paddles were extracted, and the contents of the jars were allowed to settle for $30 \mathrm{~min}$ prior to collecting approximately $1 \mathrm{~L}$ of sample. Additional details for enhanced coagulation are provided in Abbaszadegan et al. (2007) and Mayer et al. (2008).

\subsection{Experimental design}

The experiments were divided into three phases; a summary of the experimental design is provided in Table 2. The first phase (limited photocatalysis) involved the destruction and/or removal of DBP precursors with photocatalytic energy consumption values less than $5 \mathrm{kWh} / \mathrm{m}^{3}$. A threshold of $5 \mathrm{kWh} / \mathrm{m}^{3}$ was selected based on energy costs and previous experience with photocatalytic inactivation of viruses (Gerrity et al., 2008). Five energy consumption values and four $\mathrm{TiO}_{2}$ concentrations were evaluated during this phase. Enhanced coagulation was also evaluated. 
Table 2. Summary of experimental design.

\begin{tabular}{|c|c|c|c|c|c|c|c|c|c|c|}
\hline Phase & Photocatalysis & & & & & $\begin{array}{l}\text { Enhanced } \\
\text { coagulation }\end{array}$ & & & & \\
\hline & Salt River & & $\begin{array}{l}\text { CAP } \\
\text { Canal }\end{array}$ & & Notes & Salt River & & $\begin{array}{l}\text { CAP } \\
\text { Canal }\end{array}$ & & Notes \\
\hline & Raw 1 & $\begin{array}{l}\text { Raw } \\
2\end{array}$ & Raw 1 & $\begin{array}{l}\text { Raw } \\
2\end{array}$ & & Raw 1 & $\begin{array}{l}\text { Raw } \\
2\end{array}$ & Raw 1 & $\begin{array}{l}\text { Raw } \\
2\end{array}$ & \\
\hline \multirow[t]{3}{*}{$\begin{array}{l}1 \text { - Limited } \\
\text { photocatalysis }\end{array}$} & $x$ & - & $x$ & - & THMFP: $10^{\circ} \mathrm{C}$ and $28^{\circ} \mathrm{C}$ & $\mathrm{X}$ & - & $x$ & - & $\begin{array}{l}\text { THMFP: } 10^{\circ} \mathrm{C} \\
\text { and } 28^{\circ} \mathrm{C}\end{array}$ \\
\hline & & & & & $\begin{array}{l}\text { Experiments: UV, } \\
\mathrm{UV}+100 \mathrm{mg} / \mathrm{L} \mathrm{TiO}_{2} \\
\mathrm{UV}+400 \mathrm{mg} / \mathrm{L} \mathrm{TiO}_{2} \\
\mathrm{UV}+1000 \mathrm{mg} / \mathrm{L} \mathrm{TiO}_{2}\end{array}$ & & & & & $\begin{array}{l}\mathrm{FeCl}_{3} \text { dose: } 20, \\
40,60 \mathrm{mg} / \mathrm{L}\end{array}$ \\
\hline & & & & & Energy: 0-5 kWh/m $/ \mathrm{m}^{3}$ & & & & & $\begin{array}{l}\mathrm{pH}: \text { ambient, } 6.5 \text {, } \\
6.0,5.5\end{array}$ \\
\hline \multirow[t]{3}{*}{$\begin{array}{l}2 \text { - Extended } \\
\text { photocatalysis }\end{array}$} & - & $x$ & - & $x$ & THMFP at $28^{\circ} \mathrm{C}$ & - & - & - & - & - \\
\hline & & & & & $\begin{array}{l}\text { Experiment: UV + } 400 \mathrm{mg} / \mathrm{L} \\
\mathrm{TiO}_{2}\end{array}$ & & & & & \\
\hline & & & & & Energy: 0-320 kWh/m³ & & & & & \\
\hline \multirow[t]{4}{*}{$\begin{array}{l}3-\text { THM removal } \\
\text { and destruction }\end{array}$} & $x$ & $x$ & $x$ & $x$ & Prechlorination at $28^{\circ} \mathrm{C}$ & $x$ & - & - & - & $\begin{array}{l}\text { Prechlorination: } \\
28^{\circ} \mathrm{C}\end{array}$ \\
\hline & & & & & $\begin{array}{l}\text { Experiment: UV + } 400 \mathrm{mg} / \mathrm{L} \\
\mathrm{TiO}_{2}\end{array}$ & & & & & $\begin{array}{l}\mathrm{FeCl}_{3} \text { dose: } 20 \\
40,60 \mathrm{mg} / \mathrm{L}\end{array}$ \\
\hline & & & & & Energy: $0-40 \mathrm{kWh} / \mathrm{m}^{3}$ & & & & & $\begin{array}{l}\text { pH: ambient, 6.5, } \\
6.0,5.5\end{array}$ \\
\hline & & & & & $\begin{array}{l}\text { Rechlorination of Raw } 2 \\
\text { waters }^{\mathrm{a}}: 2 \mathrm{mg} / \mathrm{L} \text { and } \\
\text { THMFP }^{\mathrm{b}} \text { concentration }\end{array}$ & & & & & \\
\hline
\end{tabular}

Note that " $X$ " denotes inclusion of water sample for a particular experiment.

aRechlorination was not performed for Raw 1 samples.

bTHMFP concentration refers to the concentration necessary to target $1 \pm 0.2 \mathrm{mg} / \mathrm{L}$ of free chlorine residual in the raw water after $24 \mathrm{~h}$. 
Based on the results of limited photocatalysis, the second phase (extended photocatalysis) assessed energy consumption values up to $320 \mathrm{kWh} / \mathrm{m}^{3}$. As discussed later, limited photocatalytic treatment actually increased THM formation in the surface waters. Despite the energy-intensive nature of this extended photocatalysis phase, the intent was to validate that photocatalysis was able to reduce THM formation given sufficient reaction time. Enhanced coagulation was not evaluated during this phase.

The third phase evaluated photocatalysis and enhanced coagulation for the removal and destruction of THMs rather than precursors and THMFP. With respect to photocatalysis, first-order rate constants and electrical energy per order (EEO) of magnitude destruction were calculated for each constituent THM. Since photocatalysis quenches the chlorine residual in this type of application, rechlorination was also evaluated for the 5,10 , and $20 \mathrm{kWh} / \mathrm{m}^{3}$ samples during the Raw 2 test. Two free chlorine concentrations were assessed during this rechlorination experiment: $2 \mathrm{mg} / \mathrm{L}$ and the THMFP concentration. The THMFP concentration is the concentration necessary to achieve a free chlorine residual of $1 \pm 0.2 \mathrm{mg} / \mathrm{L}$ in the raw waters after $24 \mathrm{~h}$. For enhanced coagulation, rechlorination was not evaluated because a residual exists after jar testing.

\section{Results and discussion}

\subsection{Phase 1: effect of limited photocatalysis and enhanced coagulation on THM precursors and formation potential}

The first phase involved the destruction and/or removal of DBP precursors in water from the CAP Canal and Salt River followed by THMFP tests. Limited photocatalysis $\left(<5 \mathrm{kWh} / \mathrm{m}^{3}\right)$ was evaluated during this phase. This type of treatment and analysis is applicable to most water treatment plants where THMs have not yet formed. Therefore, it is important to target the THM precursors and then simulate their post-treatment formation to evaluate process performance. As described earlier, a threshold of $5 \mathrm{kWh} / \mathrm{m}^{3}$ was selected for photocatalysis based on energy costs and previous experience with photocatalytic inactivation of viruses (Gerrity et al., 2008). Higher levels of energy consumption may be cost prohibitive for this type of application given the high flow rates at many water treatment plants.

Based on the post-treatment water quality summary for the CAP Canal (Table 3) and Salt River (Table 4), the Photo-Cat Lab ${ }^{\circ}$ appeared to improve water quality with respect to THM precursors. The turbidity was reduced from 2.2 to $<0.2$ NTU for each sample, and the DOC and $U^{254}$ absorbance were reduced nearly $50 \%$. The results were similar between the CAP Canal and Salt River, although the Salt River had higher initial DOC and $\mathrm{UV}_{254}$ levels. Increasing $\mathrm{TiO}_{2}$ concentrations also achieved slightly improved precursor removal. Furthermore, the bromide concentration decreased by approximately $50 \%$ in many samples, presumably due to charge interactions with the ceramic membrane filter. Using a multilayer $\mathrm{TiO}_{2}$ ceramic membrane, Gestel et al. (2002) also achieved significant (up to $80 \%$ ) monovalent salt reduction. However, the bromide concentration seemed to fluctuate in the Salt River samples, and there was evidence of breakthrough over time, thereby indicating that consistent bromide removal may not be possible with continuous treatment.

Table 3. Phase 1 limited photocatalysis: summary of THM precursors for the CAP Canal.

\begin{tabular}{|l|l|l|l|l|l|l|l|}
\hline Process & Treatment & $\mathbf{p H}$ & $\begin{array}{l}\text { Turbidity } \\
(\mathbf{N T U})\end{array}$ & $\begin{array}{l}\text { DOC } \\
(\mathbf{m g ~ C} / \mathbf{L})\end{array}$ & $\left.\mathbf{U V}_{\mathbf{2 5 4}} \mathbf{( c m}^{-\mathbf{1}}\right)$ & $\begin{array}{l}\text { SUVA } \\
(\mathbf{L} / \mathbf{m g ~ m})\end{array}$ & $\begin{array}{l}\text { Bromide } \\
(\boldsymbol{\mu g} / \mathbf{L})\end{array}$ \\
\hline Raw & - & $\mathbf{8 . 5}$ & $\mathbf{2 . 2}$ & $\mathbf{5 . 7}$ & $\mathbf{0 . 0 4 6}$ & $\mathbf{0 . 8 1}$ & $\mathbf{1 0 9}$ \\
\hline UV & $0 \mathrm{kWh} / \mathrm{m}^{3}$ & 8.0 & $<0.2$ & 3.3 & 0.047 & 1.4 & 47 \\
\hline & $0.3 \mathrm{kWh} / \mathrm{m}^{3}$ & 8.0 & $<0.2$ & 3.4 & 0.047 & 1.4 & 48 \\
\hline & $1 \mathrm{kWh} / \mathrm{m}^{3}$ & 8.0 & $<0.2$ & 3.3 & 0.043 & 1.3 & 48 \\
\hline & $2 \mathrm{kWh} / \mathrm{m}^{3}$ & 8.0 & $<0.2$ & 3.4 & 0.041 & 1.2 & 57 \\
\hline & $5 \mathrm{kWh} / \mathrm{m}^{3}$ & 8.0 & $<0.2$ & 3.4 & 0.034 & 1.0 & 64 \\
\hline
\end{tabular}




\begin{tabular}{|l|l|l|l|l|l|l|l|}
\hline $\begin{array}{l}\text { Photocatalysis with } \\
100 \mathrm{mg} / \mathrm{L} \mathrm{TiO}_{2}\end{array}$ & $0 \mathrm{kWh} / \mathrm{m}^{3}$ & 8.0 & $<0.2$ & 3.1 & 0.043 & 1.4 & 45 \\
\hline & $0.3 \mathrm{kWh} / \mathrm{m}^{3}$ & 8.0 & $<0.2$ & 3.1 & 0.041 & 1.3 & 56 \\
\hline & $1 \mathrm{kWh} / \mathrm{m}^{3}$ & 8.0 & $<0.2$ & 3.2 & 0.039 & 1.2 & 54 \\
\hline & $2 \mathrm{kWh} / \mathrm{m}^{3}$ & 8.0 & $<0.2$ & 3.4 & 0.036 & 1.1 & 61 \\
\hline & $5 \mathrm{kWh} / \mathrm{m}^{3}$ & 8.0 & $<0.2$ & 3.2 & 0.027 & 0.83 & 62 \\
\hline $\begin{array}{l}\text { Photocatalysis with } \\
400 \mathrm{mg} / \mathrm{L} \mathrm{TiO}_{2}\end{array}$ & $0 \mathrm{kWh} / \mathrm{m}^{3}$ & 7.9 & $<0.2$ & 2.9 & 0.040 & 1.4 & 41 \\
\hline & $0.3 \mathrm{kWh} / \mathrm{m}^{3}$ & 7.9 & $<0.2$ & 2.9 & 0.039 & 1.3 & 46 \\
\hline & $1 \mathrm{kWh} / \mathrm{m}^{3}$ & 7.9 & $<0.2$ & 3.2 & 0.037 & 1.2 & 58 \\
\hline & $2 \mathrm{kWh} / \mathrm{m}^{3}$ & 7.9 & $<0.2$ & 3.3 & 0.033 & 1.0 & 53 \\
\hline & $5 \mathrm{kWh} / \mathrm{m}^{3}$ & 7.9 & $<0.2$ & 3.1 & 0.024 & 0.79 & 65 \\
\hline $\begin{array}{l}\text { Photocatalysis with } \\
1000 \mathrm{mg} / \mathrm{L} \mathrm{TiO}\end{array}$ & $0 \mathrm{kWh} / \mathrm{m}^{3}$ & 7.6 & $<0.2$ & 2.8 & 0.037 & 1.3 & 38 \\
\hline & $0.3 \mathrm{kWh} / \mathrm{m}^{3}$ & 7.6 & $<0.2$ & 2.9 & 0.037 & 1.3 & 49 \\
\hline & $1 \mathrm{kWh} / \mathrm{m}^{3}$ & 7.6 & $<0.2$ & 3.4 & 0.036 & 1.1 & 52 \\
\hline & $2 \mathrm{kWh} / \mathrm{m}^{3}$ & 7.6 & $<0.2$ & 3.2 & 0.031 & 1.0 & 51 \\
\hline & $5 \mathrm{kWh} / \mathrm{m}^{3}$ & 7.6 & $<0.2$ & 2.9 & 0.021 & 0.73 & 51 \\
\hline
\end{tabular}

Table 4. Phase 1 limited photocatalysis: summary of THM precursors for the Salt River.

\begin{tabular}{|c|c|c|c|c|c|c|c|}
\hline Process & Treatment & $\mathrm{pH}$ & $\begin{array}{l}\text { Turbidity } \\
\text { (NTU) }\end{array}$ & $\begin{array}{l}\text { DOC } \\
(\mathrm{mg} \mathrm{C} / \mathrm{L})\end{array}$ & $U_{254}\left(\mathrm{~cm}^{-1}\right)$ & $\begin{array}{l}\text { SUVA } \\
\text { (L/mg m) }\end{array}$ & $\begin{array}{l}\text { Bromide } \\
(\mu \mathrm{g} / \mathrm{L})\end{array}$ \\
\hline Raw & - & 8.1 & 2.2 & 7.4 & 0.110 & 1.5 & 109 \\
\hline \multirow[t]{5}{*}{ UV } & $0 \mathrm{kWh} / \mathrm{m}^{3}$ & 8.0 & $<0.2$ & 4.8 & 0.082 & 1.7 & 59 \\
\hline & $0.3 \mathrm{kWh} / \mathrm{m}^{3}$ & 8.0 & $<0.2$ & 4.7 & 0.081 & 1.7 & 55 \\
\hline & $1 \mathrm{kWh} / \mathrm{m}^{3}$ & 8.0 & $<0.2$ & 4.7 & 0.074 & 1.6 & 51 \\
\hline & $2 \mathrm{kWh} / \mathrm{m}^{3}$ & 8.0 & $<0.2$ & 4.8 & 0.067 & 1.4 & 60 \\
\hline & $5 \mathrm{kWh} / \mathrm{m}^{3}$ & 8.0 & $<0.2$ & 4.8 & 0.053 & 1.1 & 67 \\
\hline \multirow{5}{*}{$\begin{array}{l}\text { Photocatalysis with } \\
100 \mathrm{mg} / \mathrm{L} \mathrm{TiO}_{2}\end{array}$} & $0 \mathrm{kWh} / \mathrm{m}^{3}$ & 8.0 & $<0.2$ & 4.7 & 0.076 & 1.6 & 52 \\
\hline & $0.3 \mathrm{kWh} / \mathrm{m}^{3}$ & 8.0 & $<0.2$ & 4.7 & 0.072 & 1.5 & 59 \\
\hline & $1 \mathrm{kWh} / \mathrm{m}^{3}$ & 8.0 & $<0.2$ & 4.8 & 0.066 & 1.4 & 58 \\
\hline & $2 \mathrm{kWh} / \mathrm{m}^{3}$ & 8.0 & $<0.2$ & 4.8 & 0.059 & 1.2 & 64 \\
\hline & $5 \mathrm{kWh} / \mathrm{m}^{3}$ & 8.0 & $<0.2$ & 4.7 & 0.041 & 0.87 & 66 \\
\hline \multirow{5}{*}{$\begin{array}{l}\text { Photocatalysis with } \\
400 \mathrm{mg} / \mathrm{L} \mathrm{TiO}_{2}\end{array}$} & $0 \mathrm{kWh} / \mathrm{m}^{3}$ & 7.8 & $<0.2$ & 4.3 & 0.063 & 1.5 & 44 \\
\hline & $0.3 \mathrm{kWh} / \mathrm{m}^{3}$ & 7.8 & $<0.2$ & 4.4 & 0.064 & 1.5 & 47 \\
\hline & $1 \mathrm{kWh} / \mathrm{m}^{3}$ & 7.8 & $<0.2$ & 4.5 & 0.058 & 1.3 & 165 \\
\hline & $2 \mathrm{kWh} / \mathrm{m}^{3}$ & 7.8 & $<0.2$ & 4.6 & 0.051 & 1.1 & 57 \\
\hline & $5 \mathrm{kWh} / \mathrm{m}^{3}$ & 7.8 & $<0.2$ & 4.5 & 0.032 & 0.72 & 65 \\
\hline \multirow{5}{*}{$\begin{array}{l}\text { Photocatalysis with } \\
1000 \mathrm{mg} / \mathrm{L} \mathrm{TiO}_{2}\end{array}$} & $0 \mathrm{kWh} / \mathrm{m}^{3}$ & 7.9 & $<0.2$ & 4.1 & 0.058 & 1.4 & 55 \\
\hline & $0.3 \mathrm{kWh} / \mathrm{m}^{3}$ & 7.9 & $<0.2$ & 4.2 & 0.058 & 1.4 & 100 \\
\hline & $1 \mathrm{kWh} / \mathrm{m}^{3}$ & 7.9 & $<0.2$ & 4.4 & 0.054 & 1.2 & 69 \\
\hline & $2 \mathrm{kWh} / \mathrm{m}^{3}$ & 7.9 & $<0.2$ & 4.5 & 0.045 & 1.0 & 62 \\
\hline & $5 \mathrm{kWh} / \mathrm{m}^{3}$ & 7.9 & $<0.2$ & 4.4 & 0.026 & 0.59 & 110 \\
\hline
\end{tabular}


Despite these precursor reductions, SUVA increased slightly for the Salt River and by nearly $75 \%$ for the CAP Canal following the initial filtration $\left(0 \mathrm{kWh} / \mathrm{m}^{3}\right)$. With photocatalysis, the CAP Canal SUVA values decreased steadily but still exceeded the raw SUVA value after $5 \mathrm{kWh} / \mathrm{m}^{3}$. For the Salt River, all four tests demonstrated overall reductions in SUVA following photocatalytic treatment. For the CAP Canal, in particular, this data suggests that the ceramic membrane filter (with and without $\mathrm{TiO}_{2}$ ) preferentially removed non-aromatic organic material. This reduced DOC through physical removal but maintained a relatively constant $U_{254}$ value, thereby initially increasing the SUVA value. As indicated in Table 3, photolysis and photocatalysis destroyed the aromaticity of the organic content, but the energy values were insufficient to demonstrate organic mineralization, as indicated by the relatively constant DOC values over time. Accordingly, the SUVA began to decrease as the aromaticity was destroyed, but the organic material was neither removed nor destroyed following the initial physical removal.

Following the THMFP tests, photocatalysis led to increased chlorine demand and TTHM concentrations in both surface waters as the organic matter became more reactive. Fig. 2, Fig. 3 illustrate this trend for the CAP Canal and Salt River, respectively, at an incubation temperature of $28^{\circ} \mathrm{C}$. The $10^{\circ} \mathrm{C}$ and constituent THM data are not included, but a discussion of the results is provided below. The $10^{\circ} \mathrm{C}$ and $28{ }^{\circ} \mathrm{C}$ incubation temperatures yielded similar trends, but as expected, the $10^{\circ} \mathrm{C}$ samples had lower THMFP overall. With respect to individual THM constituents, chloroform contributed substantially to the increase in THMFP for the CAP Canal, whereas dibromochloromethane and bromoform formation actually decreased for each experiment. For the Salt River, chloroform formation increased moderately, and dibromochloromethane formation increased dramatically relative to the initial concentration. Initially, the higher $\mathrm{TiO}_{2}$ concentrations achieved greater DOC removal and reductions in chlorine demand, but their greater photocatalytic activity also yielded greater relative increases in THMFP over time. With respect to the CAP Canal, the $\mathrm{TiO}_{2}$ samples in Fig. 2 actually show an increase in THMFP after the initial filtration $\left(0 \mathrm{kWh} / \mathrm{m}^{3}\right)$, whereas the $\mathrm{TiO}_{2}$ samples in Fig. 3 show a decrease in THMFP at $0 \mathrm{kWh} / \mathrm{m}^{3}$ for the Salt River. The reason for this difference is unclear other than that the raw waters likely had dissimilar organic compositions, which affected the initial physical removal. The initial filtration for both sets of UV samples increased THMFP compared to the raw water, but the THMFP remained relatively constant despite UV irradiation. For the CAP Canal and Salt River, the overall trend of increasing chlorine demand and THMFP with photocatalytic treatment was consistent for all of the $\mathrm{TiO}_{2}$ experiments.

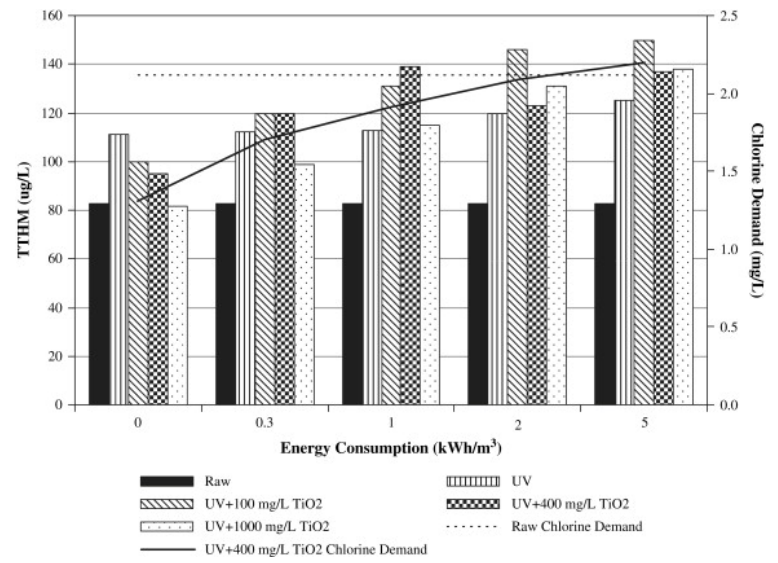

Fig. 2. Phase 1 limited photocatalysis: THMFP $\left(28^{\circ} \mathrm{C}\right)$ and $24-\mathrm{h}$ chlorine demand $\left(28^{\circ} \mathrm{C}\right)$ for the Raw 1 water from the CAP Canal. 


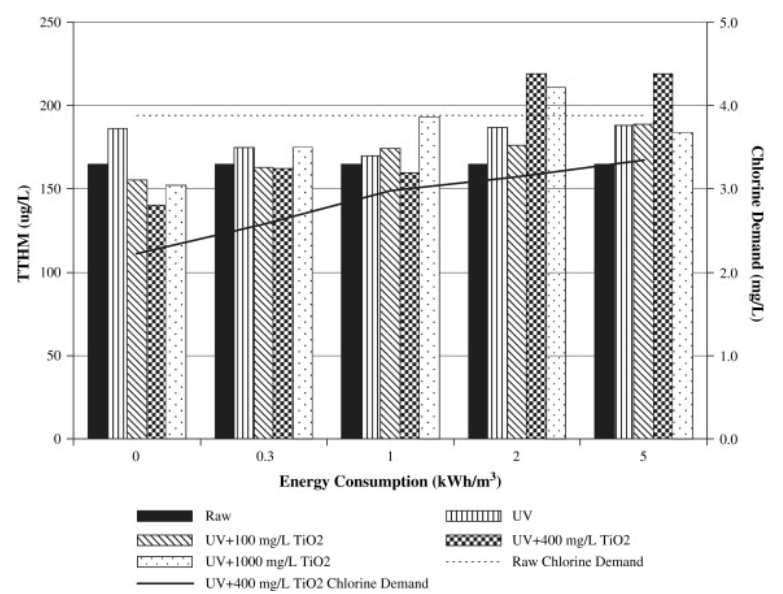

Fig. 3. Phase 1 limited photocatalysis: THMFP $\left(28^{\circ} \mathrm{C}\right)$ and 24 -h chlorine demand $\left(28^{\circ} \mathrm{C}\right)$ for the Raw 1 water from the Salt River.

In contrast, many studies have only reported decreases in THM formation after advanced oxidation (Hand et al., 1995, Chin and Berube, 2005, Toor and Mohseni, 2007, Liu et al., 2008, Richardson et al., 1996), although there are exceptions (Kleiser and Frimmel, 2000, Glauner et al., 2005). Similar to the results of this study, Kleiser and Frimmel (2000) observed a 20\% increase in THMFP after treatment with $\mathrm{UV} / \mathrm{H}_{2} \mathrm{O}_{2}$ and short irradiation times. Glauner et al. (2005) also observed increases in THMFP following ozone/UV and ozone $/ \mathrm{H}_{2} \mathrm{O}_{2}$ treatment, but ozone alone was able to reduce THMFP in all samples. They explained that ozone selectively attacks double bonds, deprotonated amines, and activated aromatic systems, whereas the nonselective hydroxyl radicals form reactive compounds conducive to THM formation. Based on these findings, further study is necessary to determine which parameters accurately predict reductions in THMFP for advanced oxidation processes. Organic composition (i.e., fractionation) and size characteristics may be better indicators of DBP mitigation than aggregate parameters such as DOC. Zhao et al. (2006) reported that organic matter with molecular weights less than 500 Da produce a disproportionate share of THMs after chlorination. Therefore, advanced oxidation must break down organic matter beyond this "critical" molecular weight before a reduction in THMFP is achieved.

In contrast to photocatalysis, enhanced coagulation demonstrated reductions in all of the measured precursors and exceeded the requirements of the Stage 2 D/DBPR with respect to TTHMs in the CAP Canal, as indicated in Fig. 4. Using $40 \mathrm{mg} / \mathrm{L} \mathrm{FeCl}_{3}$ without manual $\mathrm{pH}$ adjustment achieved a $20 \%$ reduction in THMFP, whereas a $\mathrm{pH}$ adjustment down to 5.5 achieved a 50\% reduction in THMFP. For both surface waters, the formation of constituent THMs experienced similar relative reductions. As expected, chlorine demand generally decreased over time as well. Although enhanced coagulation was not as effective for the Salt River (Fig. 5), both surface waters experienced reductions in THMFP for $10^{\circ} \mathrm{C}$ and $28^{\circ} \mathrm{C}$ incubation temperatures, whereas photocatalysis increased THMFP. 


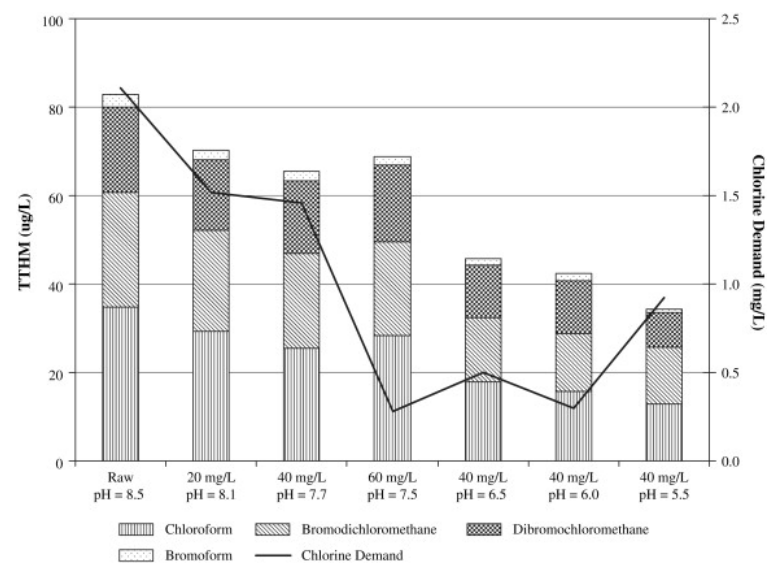

Fig. 4. Phase 1 enhanced coagulation: $\operatorname{THMFP}\left(28^{\circ} \mathrm{C}\right)$ and $24-\mathrm{h}$ chlorine demand $\left(28^{\circ} \mathrm{C}\right)$ for the Raw 1 water from the CAP Canal.

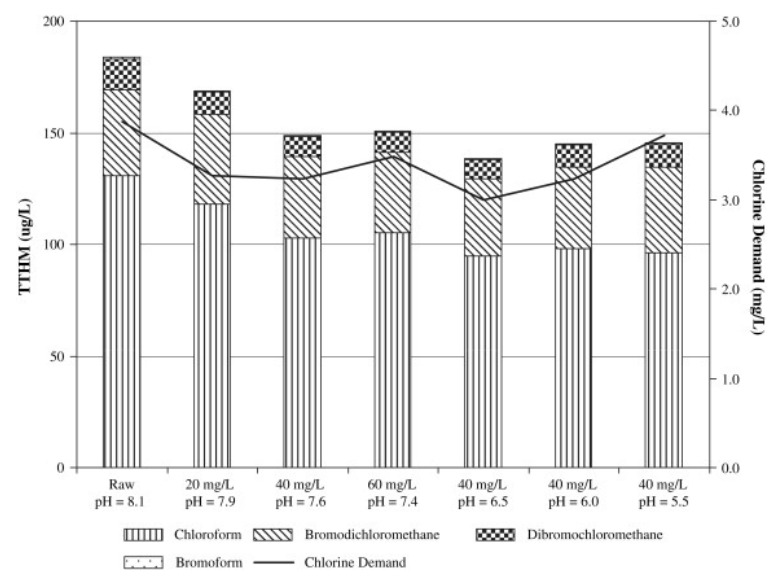

Fig. 5. Phase 1 enhanced coagulation: THMFP $\left(28^{\circ} \mathrm{C}\right)$ and 24 -h chlorine demand $\left(28^{\circ} \mathrm{C}\right)$ for the Raw 1 water from the Salt River.

\subsection{Phase 2: effect of extended photocatalysis on THM precursors and formation potential}

As discussed earlier, Kleiser and Frimmel (2000) reported a significant increase in THMFP with UV/ $\mathrm{H}_{2} \mathrm{O}_{2}$ and short irradiation times, but after extended $\mathrm{UV} / \mathrm{H}_{2} \mathrm{O}_{2}$ treatment, the THMFP eventually decreased more than $70 \%$ relative to the raw water. In order to duplicate this result and validate $\mathrm{TiO}_{2}$ photocatalysis for $\mathrm{DBP}$ mitigation, the Salt River and CAP Canal were tested with $400 \mathrm{mg} / \mathrm{L} \mathrm{TiO}_{2}$ and extended photocatalysis (energy consumption values up to $320 \mathrm{kWh} / \mathrm{m}^{3}$ ). Fig. 6 illustrates the effect of extended photocatalysis on DOC and chlorine demand in the two surface waters. Similar to the limited photocatalysis experiments, the initial filtration $\left(0 \mathrm{kWh} / \mathrm{m}^{3}\right)$ achieved a high removal of DOC and chlorine demand. With limited photocatalysis $\left(0-10 \mathrm{kWh} / \mathrm{m}^{3}\right), \mathrm{DOC}$ remained relatively constant, which indicated chemical "rearrangement" rather than mineralization, and the chlorine demand increased. In contrast to the limited photocatalysis experiments but similar to the findings of Kleiser and Frimmel (2000), extended photocatalysis $\left(>10 \mathrm{kWh} / \mathrm{m}^{3}\right)$ yielded a consistent decrease in DOC and eventually chlorine demand. Ultimately, these experiments demonstrated $90 \%$ removal and mineralization of DOC and nearly complete destruction of $U_{2} V_{24}$ and SUVA for both surface waters. Bromide concentrations fluctuated between $50 \%$ removal and a 50\% increase for the CAP Canal, but a relatively consistent $15-20 \%$ removal was observed for the Salt River. The bromide fluctuations may be the result of transient conditions related to the ceramic membrane air hammer. 


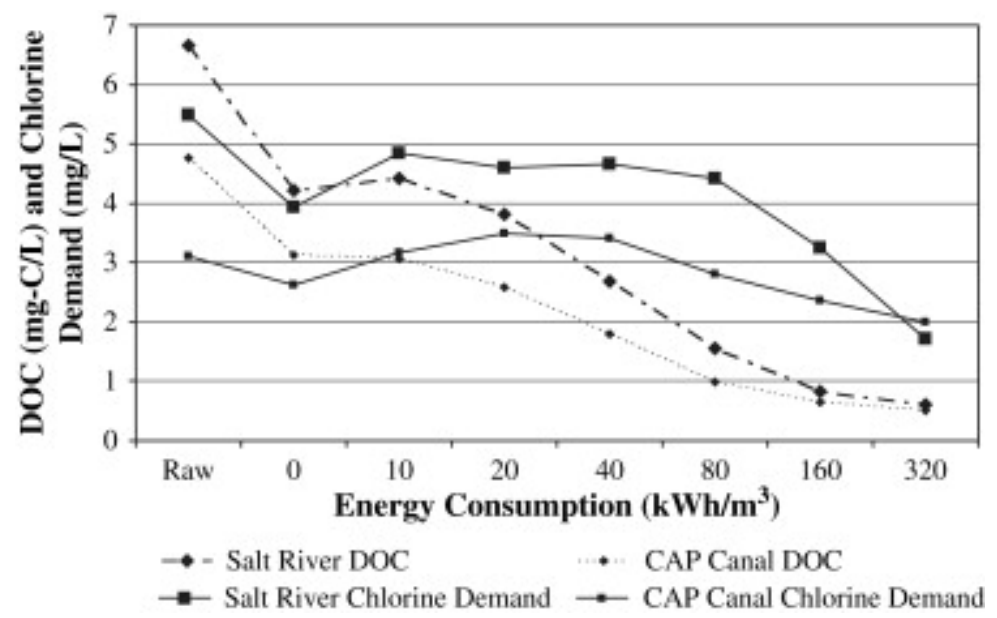

Fig. 6. Phase 2 extended photocatalysis: DOC and chlorine demand $\left(28^{\circ} \mathrm{C}\right)$ for the Raw 2 surface waters following photocatalytic treatment.

In addition to standard organic analyses, high-performance size exclusion chromatography (HPSEC) was performed for these samples. Hand et al. (1995) and Liu et al. (2008) also evaluated changes in apparent molecular weight of NOM after advanced oxidation using ultrafiltration and HPSEC, respectively. These analyses are important because several studies report correlations between the presence of low molecular weight compounds and increased THM formation (Amy et al., 1992, Zhao et al., 2006). Magnified chromatograms (10²$10^{4} \mathrm{Da}$ ) for the CAP Canal and Salt River are provided in Fig. 7B and D, respectively. These peaks clearly illustrate the "rearrangement" of organic matter during photocatalysis. The initial filtration $\left(0 \mathrm{kWh} / \mathrm{m}^{3}\right)$ reduced the raw peak slightly. The first two photocatalytic treatments yielded a small decrease in peak magnitude and a more dramatic horizontal shift toward smaller molecular weights. As described in Zhao et al. (2006), this horizontal shift toward 500 Da may be responsible for the increased THMFP based on the similar DOC response but possibly greater reactivity. The remaining photocatalytic treatments shifted the organic matter toward smaller molecular weights and dramatically reduced the magnitudes of the peaks. In Fig. 7A (CAP Canal) and C (Salt River), sets of large peaks, which likely represent organic acids in the water, can be seen at approximately $10^{2} \mathrm{Da}$. There is no noticeable horizontal translation, but the magnitude of these peaks decreased with energy consumption up to $160 \mathrm{kWh} / \mathrm{m}^{3}$. However, the DOC response for $320 \mathrm{kWh} / \mathrm{m}^{3}$ actually increased above that of $160 \mathrm{kWh} / \mathrm{m}^{3}$ for both waters. The cause for this increase is unclear, but it is possible that the additional treatment caused a significant rearrangement of larger molecules to this molecular weight. In contrast to Fig. 7A and $\mathrm{C}$, the magnified chromatograms in Fig. 7B and D illustrate dramatic reductions in DOC response at $320 \mathrm{kWh} / \mathrm{m}^{3}$. These results indicate that there may be a point where photocatalytic "rearrangement" of larger molecules exceeds mineralization of some recalcitrant compounds with low molecular weights.
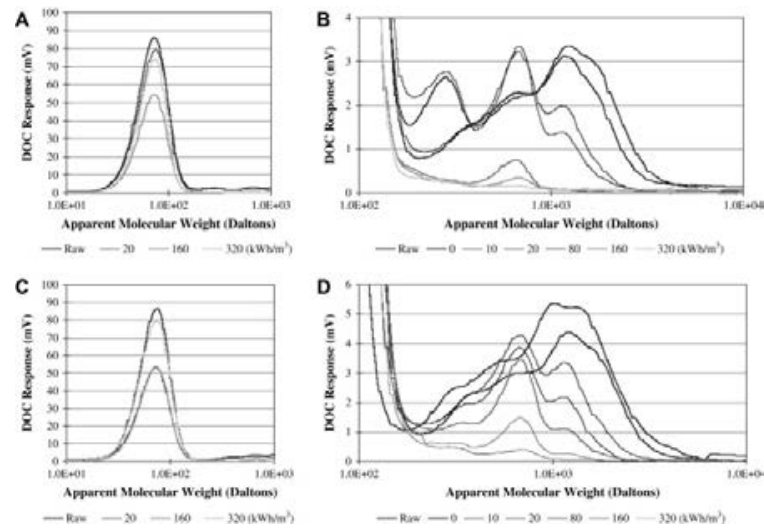
Fig. 7. Phase 2 extended photocatalysis: Size exclusion chromatograms for the CAP Canal (A and B) and the Salt River ( $C$ and D) after photocatalytic treatment with $400 \mathrm{mg} / \mathrm{L} \mathrm{TiO}_{2}$. Fig. A and $\mathrm{C}$ show the portion of the chromatograms between $10^{1}$ and $10^{3} \mathrm{Da}$ and primarily illustrate organic mineralization. Fig. $\mathrm{B}$ and $\mathrm{D}$ provide magnified views between $10^{2}$ and $10^{4} \mathrm{Da}$ and primarily illustrate organic "rearrangement".

The THMFP tests at $28^{\circ} \mathrm{C}$ (Fig. 8) supported the DBP precursor and HPSEC results in that extended photocatalysis dramatically reduced THMFP in both the CAP Canal and Salt River samples. The initial filtration $\left(0 \mathrm{kWh} / \mathrm{m}^{3}\right)$ reduced THMFP in both surface waters, but as with limited photocatalysis in the previous phase, THMFP increased sharply with energy consumption values up to $20 \mathrm{kWh} / \mathrm{m}^{3}$. However, after $20 \mathrm{kWh} / \mathrm{m}^{3}$, THMFP decreased dramatically to TTHM levels of approximately $5 \mu \mathrm{g} / \mathrm{L}$. The sharp decrease in THMFP was initiated primarily by reductions in chloroform formation but followed quickly by other constituents. Although at very low concentrations, bromoform formation increased rapidly in both surface waters at energy values up to $80 \mathrm{kWh} / \mathrm{m}^{3}$ before decreasing thereafter. For the Salt River, formation of all of the brominated THMs increased dramatically for energy values up to $80 \mathrm{kWh} / \mathrm{m}^{3}$. Based on absolute concentrations, chloroform was the most critical constituent in both source waters.

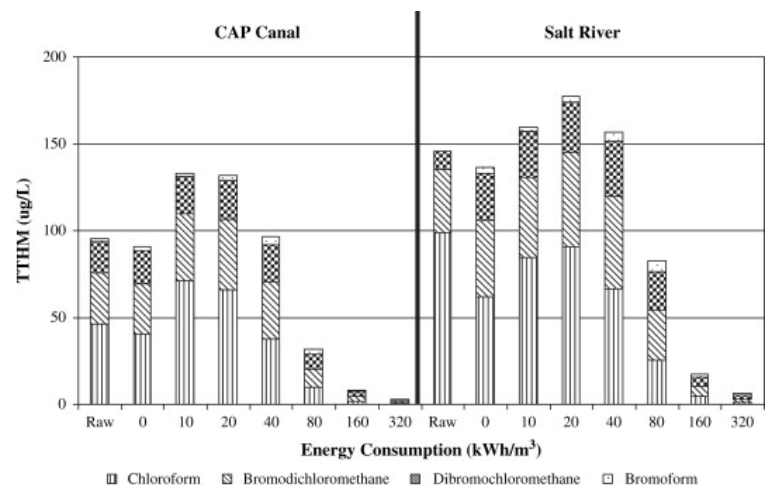

Fig. 8. Phase 2 extended photocatalysis: THMFP $\left(28^{\circ} \mathrm{C}\right)$ for the Raw 2 surface waters following photocatalytic treatment with $400 \mathrm{mg} / \mathrm{L} \mathrm{TiO}_{2}$.

\subsection{Phase 3: prechlorination followed by THM removal and destruction}

Based on the results from the limited and extended photocatalysis phases, implementing $\mathrm{TiO}_{2}$ photocatalysis for DBP mitigation is highly energy intensive. For applications with high flow rates, such as a water treatment plant, photocatalysis may be a costly proposition. However, it may be possible to exploit the benefits of photocatalysis in a modified DBP application, such as targeting noncompliant locations in the distribution system. Phase 3 addresses this type of application by evaluating the removal and destruction of THMs rather than precursors. THMs were formed by prechlorinating the surface waters prior to photocatalysis with $400 \mathrm{mg} / \mathrm{L} \mathrm{TiO}_{2}$ and enhanced coagulation.

Photocatalytic removal and destruction of THMs in the prechlorinated CAP Canal and Salt River water are illustrated in Fig. 9, Fig. 10, respectively. The horizontal axes indicate different combinations of photocatalytic energy consumption $\left(\mathrm{kWh} / \mathrm{m}^{3}\right.$ ) and rechlorination $(\mathrm{mg} / \mathrm{L})$. The columns designated as $0 \mathrm{mg} / \mathrm{L} \mathrm{refer}$ only to THM removal and destruction and do not account for rechlorination. In general, filtration alone $\left(0 \mathrm{kWh} / \mathrm{m}^{3}\right)$ accounted for a very small decrease in THM concentration, but photocatalysis eventually reduced the TTHM levels to less than $25 \mu \mathrm{g} / \mathrm{L}$ in both surface waters. Enhanced coagulation achieved relatively constant TTHM removals of $20-30 \%$ in the Salt River water, regardless of $\mathrm{FeCl}_{3}$ dose and $\mathrm{pH}$ (Table 5). Each of the constituent THMs was removed to a similar extent with enhanced coagulation. 


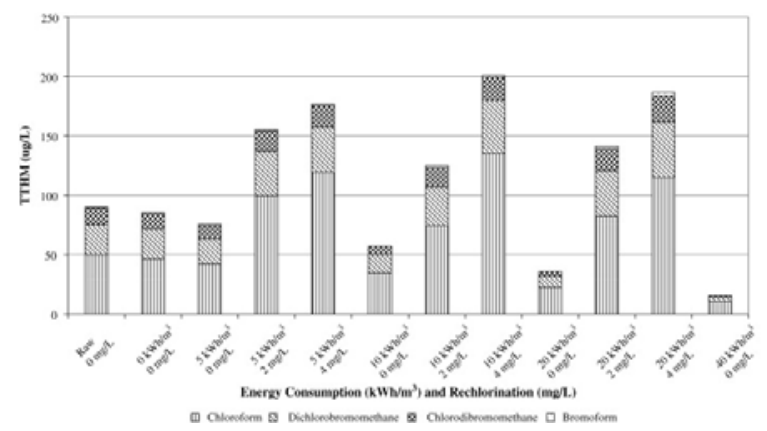

Fig. 9. Phase 3: photocatalytic THM destruction and rechlorination $\left(28^{\circ} \mathrm{C}\right)$ with the Raw 2 water from the CAP Canal.

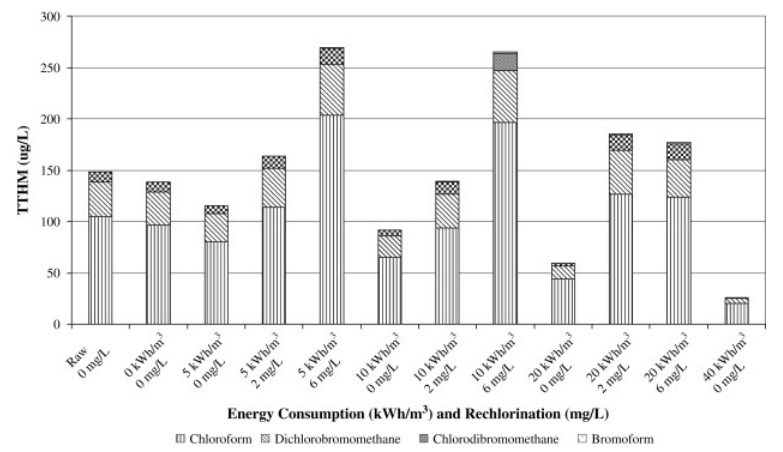

Fig. 10. Phase 3: photocatalytic THM destruction and rechlorination $\left(28^{\circ} \mathrm{C}\right)$ with the Raw 2 water from the Salt River.

Table 5. Phase 3: THM removal with enhanced coagulation (Raw 1 water from the Salt River).

\begin{tabular}{|l|l|l|l|l|l|l|}
\hline Treatment & $\mathrm{CHCl}_{3}$ & $\mathrm{CHBrCl}_{2}$ & $\mathrm{CHBr}_{2} \mathrm{Cl}$ & $\mathrm{CHBr}_{3}$ & TTHM & \% Removal of TTHMs \\
\hline Raw & 108 & 40 & 10 & $<0.5$ & 157 & - \\
\hline $\begin{array}{l}20 \mathrm{mg} / \mathrm{L} \mathrm{FeCl}_{3} \\
\mathrm{pH}=7.9\end{array}$ & 79 & 29 & 8.0 & $<0.5$ & 116 & $26 \%$ \\
\hline $\begin{array}{l}40 \mathrm{mg} / \mathrm{L} \mathrm{FeCl}_{3} \\
\mathrm{pH}=7.8\end{array}$ & 76 & 29 & 8.2 & $<0.5$ & 113 & $28 \%$ \\
\hline $\begin{array}{l}60 \mathrm{mg} / \mathrm{L} \mathrm{FeCl}_{3} \\
\mathrm{pH}=7.6\end{array}$ & 79 & 29 & 8.1 & $<0.5$ & 116 & $26 \%$ \\
\hline $\begin{array}{l}40 \mathrm{mg} / \mathrm{L} \mathrm{FeCl}_{3} \\
\mathrm{pH}=6.5\end{array}$ & 76 & 30 & 8.0 & $<0.5$ & 114 & $27 \%$ \\
\hline $\begin{array}{l}40 \mathrm{mg} / \mathrm{L} \mathrm{FeCl}_{3} \\
\mathrm{pH}=6.0\end{array}$ & 79 & 31 & 8.1 & $<0.5$ & 118 & $25 \%$ \\
\hline $\begin{array}{l}40 \mathrm{mg} / \mathrm{L} \mathrm{FeCl}_{3} \\
\mathrm{pH}=5.5\end{array}$ & 82 & 32 & 8.4 & $<0.5$ & 122 & $22 \%$ \\
\hline
\end{tabular}

With respect to photocatalysis, first-order rate constants and electrical energy per order (EEO) of magnitude destruction are provided in Table 6. The constituent THMs were destroyed the following relative rates: bromoform $>$ dibromochl-oromethane $>$ bromodichloromethane $>$ chloroform. The two surface waters demonstrated similar relative rates of destruction, but the rate constants show a large difference between the Raw 1 and Raw 2 experiments. Although the THM precursor parameters (e.g., DOC, UV 254 , etc.) were similar between the different sampling dates (Table 1), the chlorine demands were considerably higher for the Raw 2 samples. Since the Raw 2 samples were collected during the rainy season in the study area, runoff may have changed the organic characteristics in a manner that increased radical demand, thereby slowing the destruction 
of THMs. In contrast to many of the pharmaceuticals and endocrine disruptors reported in the photocatalysis study of Benotti et al. (2009), the THMs seem to have significantly lower rate constants, comparable to those of perfluorooctanesulfonic acid (PFOS), Tris(2-chloroisopropyl) phosphate (TCPP), and Tris(2-chloroethyl) phosphate (TCEP). 
Table 6. Phase 3: first-order rate constants and EEOs for photocatalytic THM destruction.

\begin{tabular}{|c|c|c|c|c|c|c|c|c|}
\hline THM & Salt River & & & & CAP Canal & & & \\
\hline & Raw 1 ${ }^{\text {a }}$ & & Raw $2^{b}$ & & Raw 1 ${ }^{\mathrm{a}}$ & & Raw $2^{b}$ & \\
\hline & $k\left(\mathrm{~m}^{3} / \mathrm{kWh}\right)$ & EEO $\left(\mathrm{kWh} / \mathrm{m}^{3}\right)$ & $k\left(\mathrm{~m}^{3} / \mathrm{kWh}\right)$ & EEO $\left(\mathrm{kWh} / \mathrm{m}^{3}\right)$ & $k\left(\mathrm{~m}^{3} / \mathrm{kWh}\right)$ & $\operatorname{EEO}\left(\mathrm{kWh} / \mathrm{m}^{3}\right)$ & $k\left(\mathrm{~m}^{3} / \mathrm{kWh}\right)$ & EEO $\left(\mathrm{kWh} / \mathrm{m}^{3}\right)$ \\
\hline $\mathrm{CHCl}_{3}$ & $0.071(0.937)^{c}$ & 32 & $0.039(0.999)$ & 59 & $0.068(0.946)$ & 34 & $0.036(0.993)$ & 64 \\
\hline $\mathrm{CHBrCl}_{2}$ & $0.081(0.979)$ & 28 & $0.048(0.997)$ & 48 & \begin{tabular}{|c|}
$0.084(0.990)$ \\
\end{tabular} & 27 & $0.049(0.996)$ & 47 \\
\hline $\mathrm{CHBr}_{2} \mathrm{Cl}$ & $0.091(0.956)$ & 25 & $0.064(0.997)$ & 36 & $0.097(0.995)$ & 24 & $0.064(0.996)$ & 36 \\
\hline $\mathrm{CHBr}_{3}$ & $N / A^{d}$ & & & & $0.12(0.972)$ & 19 & $0.071(0.999)$ & 33 \\
\hline
\end{tabular}

aValues determined from 10 time points.

bValues determined from 5 time points.

$c R^{2}$ values in parentheses.

dBromoform did not form in the Salt River water.

If this type of process is incorporated into the distribution system, photocatalysis will affect other parameters of interest. For example, assuming energy consumption values similar to those in Table 6 , photocatalysis would provide significant inactivation of bacteria, viruses, and parasites. On the other hand, photocatalysis would likely increase the amount of assimilable organic carbon (AOC) through organic degradation, which may promote downstream biofilm growth. According to Watts and Linden (2007), UV irradiation of free chlorine or chloramine can also lead to a number of potentially beneficial (e.g., hydroxyl radicals) or harmful (e.g., nitrate and nitrite) byproducts. There is also the potential for chlorine radical formation, but it is unclear how these radicals would affect water treatment. Due to its use of UV light, photocatalysis would form similar byproducts and ultimately destroy the chlorine residual present in the distribution system, thereby necessitating rechlorination.

In order to address this issue, rechlorination with two different free chlorine concentrations was evaluated during the Phase 3 experiments. For the three energy consumption values tested, rechlorination caused a dramatic increase in TTHMs, primarily due to the formation of chloroform and bromodichloromethane. Photocatalysis initially reduced the TTHM concentration well below $80 \mu \mathrm{g} / \mathrm{L}$, as indicated by the $0 \mathrm{mg} / \mathrm{L}$ columns, but rechlorination easily exceeded the MCL for TTHMs. Rodriguez et al. (2007) also reported a spike in THMs and HAAs after standard rechlorination in Canadian distribution systems, albeit without advanced oxidation and to a much lower extent. However, a more significant issue may be the interaction of organic matter and chlorine radicals. The formation of chlorine radicals after UV irradiation of free chlorine (Watts and Linden, 2007) may increase the formation potential of chloroform and bromodichloromethane, as indicated by Cassan et al. (2006). Since chloroform and bromodichloromethane were the dominant species after rechlorination in Phase 3, chlorine radicals may be a significant issue and warrant further study.

Similar to the data from the first two phases, this data suggests that complete organic mineralization may be required to achieve the desired goals, which negates the energy savings for THMs in comparison to precursors and THMFP. It may be possible to mitigate this rechlorination effect with alternative means, but further research is needed to elucidate and explore possible strategies. Although less effective than free chlorine with respect to disinfection, chloramines are more stable in the distribution system and may prevent the spike in THM concentrations. With respect to energy requirements, full-scale implementation with finished drinking water, rather than raw surface water, may yield higher efficiencies. Other optimization 
strategies may include the addition of high-efficiency hydroxyl radical scavengers, which may reduce photocatalytic recombination and promote reductive dechlorination of the THMs.

\section{Conclusions}

Advanced oxidation, including $\mathrm{TiO}_{2}$ photocatalysis, is a powerful technology that can be used in a variety of contexts. Photocatalysis simultaneously provides adsorption, oxidation, and reduction pathways and has been used to remove, destroy, and inactivate numerous microbes and contaminants of emerging concern. Although effective for many specific compounds, including pharmaceuticals and endocrine disruptors, outstanding issues need to be addressed before photocatalysis should be implemented for DBP mitigation. This study demonstrated that limited photocatalysis may exacerbate THM problems. Extended photocatalysis can reduce THMFP dramatically, but the energy requirements are likely infeasible for treatment plant applications. As demonstrated, enhanced coagulation is an effective means of DBP mitigation, yet downsides such as chemical storage, chemical feeds, and sludge disposal must be taken into consideration. When focusing on photocatalytic destruction of THMs rather than precursors and formation potential, treatment goals can be achieved with considerably lower energy consumption, but several problems still exist. Despite the energy reduction and reduced flows when treating THMs in the distribution system, the energy and associated costs may still be too high for many utilities. Optimization of this process should be considered in future studies to address these relatively high energy requirements. Also, rechlorination still poses an issue that must be addressed before this application is feasible. In general, this technology has a number of promising aspects but should be considered on a caseby-case basis.

\section{Acknowledgments}

This research was supported by the National Science Foundation (NSF) Water Quality Center at Arizona State University. This work was performed while Daniel Gerrity was on appointment as a United States Department of Homeland Security (DHS) Fellow under the DHS Scholarship and Fellowship Program. All opinions expressed in this paper are the authors' and do not necessarily reflect the policies and views of NSF, DHS, or Purifics.

We would like to thank Binga Talabi, Laura McCasland, Kathy Gettens, George Gonzalez, and Susan Butler at the City of Scottsdale Water Campus for providing the THM analyses. We would also like to thank Paul Westerhoff and his students Chao-An Chiu, Aaron Dotson, and Florian Eveno at Arizona State University for their laboratory assistance and insight. Finally, we would like to thank Tony Powell and Brian Butters of Purifics for use of the PhotoCat.

\section{References}

Abbaszadegan et al., 2007. M. Abbaszadegan, B.K. Mayer, H. Ryu, N. Nwachuku. Efficacy of removal of CCL viruses under enhanced coagulation conditions. Environ. Sci. Technol., 41 (3) (2007), pp. 971-977

Amirtharajah et al., 1993. A. Amirtharajah, K.E. Dennett, A. Studstill. Ferric chloride coagulation for removal of dissolved organic matter and trihalomethane precursors. Water Sci. Technol., 27 (1993), pp. 113-121

Amy et al., 1992. G.L. Amy, R.A. Sierka, J. Bedessem, D. Price, L. Tan. Molecular size distributions of dissolved organic matter. J. AWWA, 84 (1992), pp. 67-75 
Barreto et al., 1995. R.D. Barreto, K.A. Gray, K. Anders. Photocatalytic degradation of methyl-tert-butyl ether in TiO ${ }_{2}$ slurries: a proposed reaction scheme. Water Res., 29 (5) (1995), pp. 1243-1248

Benotti et al., 2009. M.J. Benotti, B.D. Stanford, E.C. Wert, S.A. Snyder. Evaluation of a photocatalytic reactor membrane pilot system for the removal of pharmaceuticals and endocrine disrupting compounds from water. Water Res., 43 (6) (2009), pp. 1513-1522

Cassan et al., 2006. D. Cassan, B. Mercier, F. Castex, A. Rambaud. Effects of medium-pressure UV lamps radiation on water quality in a chlorinated indoor swimming pool. Chemosphere, 62 (2006), pp. 1507-1513

Chen et al., 2007. C. Chen, X. Zhang, W. He, W. Lu, H. Han. Comparison of seven kinds of drinking water treatment processes to enhance organic material removal: a pilot test. Sci. Total Environ., 382 (2007), pp. 93-102

Childress et al., 1999. A.E. Childress, E.M. Vrijenhoek, M. Elimelech, T.S. Tanaka, M.D. Beuhler. Particulate and THM precursor removal with ferric chloride. J. Environ. Eng., 125 (1999), pp. 1054-1061

Chin and Berube, 2005. A. Chin, P.R. Berube. Removal of disinfection by-product precursors with ozone-UV advanced oxidation process. Water Res., 39 (2005), pp. 2136-2144

Cho et al., 2005. M. Cho, H. Chung, W. Choi, J. Yoon. Different inactivation behaviors of MS-2 phage and Escherichia coli in $\mathrm{TiO}_{2}$ photocatalytic disinfection. Appl. Environ. Microbiol., 71 (1) (2005), pp. 270-275

Crittenden et al., 2005. J.C. Crittenden, R.R. Trussell, D.W. Hand, K.J. Howe, G. Tchobanoglous (Eds.), Water Treatment: Principals and Design (second ed.), John Wiley, New York (2005)

Gerrity et al., 2008. D. Gerrity, H. Ryu, J. Crittenden, M. Abbaszadegan. Photocatalytic inactivation of viruses using titanium dioxide and low-pressure UV light. J. Environ. Sci. Health, Part A, 43 (2008), pp. 1261-1270

Gestel et al., 2002. T.V. Gestel, C. Vandecasteele, A. Buekenhoudt, C. Dotremont, J. Luyten, R. Leysen, B. Van der Bruggen, G. Maes. Salt retention in nanofiltration with multilayer ceramic $\mathrm{TiO}_{2}$ membranes. J. Memb. Sci., 209 (2002), pp. 379-389

Glauner et al., 2005. T. Glauner, F. Kunz, C. Zwiener, F.H. Frimmel. Elimination of swimming pool water disinfection by-products with advanced oxidation processes (AOPs). Acta Hydrochim. Hydrobiol., 33 (6) (2005), pp. 585-594

Hand et al., 1995. D.W. Hand, D.L. Perram, J.C. Crittenden. Destruction of DBP precursors with catalytic oxidation. J. AWWA, 87 (6) (1995), pp. 84-96

Her et al., 2002. N. Her, G. Amy, D. Foss, J. Cho, Y. Yoon, P. Kosenka. Optimization of method for detecting and characterizing NOM by HPLC - size exclusion chromatography with UV and on-line DOC detection. Environ. Sci. Technol., 36 (2002), pp. 1069-1076

Jacangelo et al., 1995. J.G. Jacangelo, J. DeMarco, D.M. Owen, S.J. Randtke. Selected process for removing NOM: an overview. J. AWWA, 87 (1) (1995), pp. 64-77

Jofre et al., 1995. J. Jofre, E. Olle, F. Ribas, A. Vidal, F. Lucena. Potential usefulness of bacteriophages that infect Bacteroides fragilis as model organisms for monitoring virus removal in drinking water treatment plants. Appl. Environ. Microbiol., 61 (1995), pp. $3227-3231$

Kaneco et al., 2004. S. Kaneco, M.A. Rahman, T. Suzuki, H. Katsumata, K. Ohta. Optimization of solar photocatalytic degradation conditions of bisphenol A in water using titanium dioxide. J. Photochem. Photobiol. A: Chem., 163 (3) (2004), pp. 419-424

Kastl et al., 2004. G. Kastl, A. Sathasivan, I. Fisher, J. van Leewen. Modeling DOC removal by enhanced coagulation. J. AWWA, 96 (2004), pp. 79-89

Kleiser and Frimmel, 2000. G. Kleiser, F.H. Frimmel. Removal of precursors for disinfection by-products (DBPs) - differences between ozone- and OHradical-induced oxidation. Sci. Total Environ., 256 (2000), pp. 1-9

Liu et al., 2008. S. Liu, M. Lim, R. Fabris, C. Chow, M. Drikas, R. Amal. TiO ${ }_{2}$ photocatalysis of natural organic matter in surface water: impact on trihalomethane and haloacetic acid formation potential. Environ. Sci. Technol, 42 (2008), pp. 6218-6223 
Mayer et al., 2008. B.K. Mayer, H. Ryu, M. Abbaszadegan. Treatability of U.S. environmental protection agency contaminant candidate list viruses: removal of coxsackievirus and echovirus using enhanced coagulation. Environ. Sci. Technol., 42 (18) (2008), pp. 6890-6896

Matsunaga et al., 1988. T. Matsunaga, R. Tomoda, T. Nakajima, N. Nakamura, T. Komine. Continuous-sterilization system that uses photosemiconductor powders. Appl. Environ. Microbiol., 54 (6) (1988), pp. 1330-1333

National Weather Service, 2008. National Weather Service. http://www.weather.gov/climate/index.php?wfo=psr (2008)

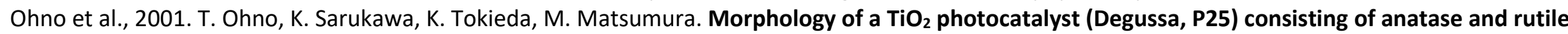
crystalline phases. J. Catal., 203 (1) (2001), pp. 82-86

Orlov et al., 2007. A. Orlov, D.A. Jefferson, M. Tikhov, R.M. Lambert. Enhancement of MTBE photocatalytic degradation by modification of TiO 2 with gold nanoparticles. Catal. Commun., 8 (5) (2007), pp. 821-824

Richardson, 2003. S.D. Richardson. Disinfection by-products and other emerging contaminants in drinking water. Trends Anal. Chem., 22 (10) (2003), pp. 666-684

Richardson et al., 1996. S.D. Richardson, A.D. Thruston Jr., T.W. Collette. Identification of TiO ${ }_{2} / U_{V}$ disinfection byproducts in drinking water. Environ. Sci. Technol., 30 (1996), pp. 3327-3334

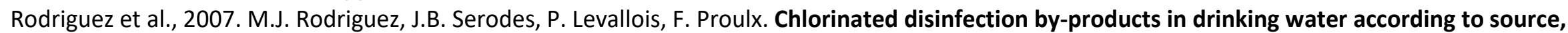
treatment, season, and distribution location. J. Environ. Eng. Sci., 6 (2007), pp. 355-365

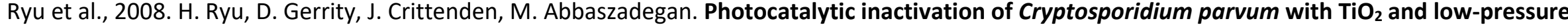
ultraviolet irradiation. Water Res., 42 (6-7) (2008), pp. 1523-1530

Thiruvenkatachari et al., 2007. R. Thiruvenkatachari, T.O. Kwon, J.C. Jun, S. Balaji, M. Matheswaran, I.S. Moon. Application of several advanced oxidation processes for the destruction of terephthalic acid (TPA). J. Hazard. Mater., 142 (1-2) (2007), pp. 308-314

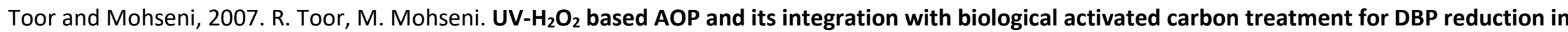
drinking water. Chemosphere, 66 (2007), pp. 2087-2095

USEPA, 2006. USEPA. National primary drinking water regulations: stage $\mathbf{2}$ disinfectants and disinfection byproducts rule; Final rule. 40 CFR Parts $\mathbf{9}$ 141 and 142. Fed. Regist., 71 (2) (2006), p. 388

Volk et al., 2000. C. Volk, K. Bell, E. Ibrahim, D. Verges, G. Amy, M. Lechevallier. Impact of enhanced and optimized coagulation on removal of organic matter and its biodegradable fraction in drinking water. Water Res., 34 (2000), pp. 3247-3257

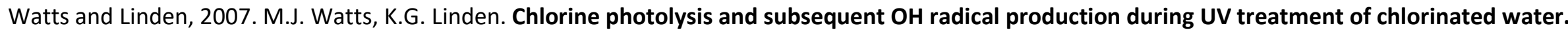
Water Res., 41 (2007), pp. 2871-2878

Yu et al., 2006. J.C. Yu, T.Y. Kwong, Q. Luo, Z. Cai. Photocatalytic oxidation of triclosan. Chemosphere, 65 (3) (2006), pp. 390-399

Zhao et al., 2006. Z.Y. Zhao, J.D. Gu, X.J. Fan, H.B. Li. Molecular size distribution of dissolved organic matter in water of the Pearl River and trihalomethane formation characteristics with chlorine and chlorine dioxide treatments. J. Hazard. Mater., B134 (2006), pp. 60-66 